\title{
Media influence on body self-perception in academics of the health area
}

\author{
Viviane Carla Sousa e Silva ${ }^{a}$, Pablo Henrique Delmondes ${ }^{a}$,Suiani Priscila Roewer ${ }^{a}$. \\ ${ }^{a}$ Grupo de Pesquisa em Ciências Estéticas e Cosméticas das Faculdades Unidas do Vale do Araguaia/UNIVAR \\ - R. Moreira Cabral, 1000 - Setor Mariano, Barra do Garças - MT, 78600-000.
}

\begin{abstract}
.
Body image care is a major concern these days, especially for women, who are always looking for ways to adjust their appearance to what is considered acceptable. The dissatisfaction with body image tends to increase according to the exposure of beautiful bodies by the media, which is always creating new standards of beauty. From this perspective, this study aimed to analyze the influence of the media on the self-perception of the body in academics regularly enrolled in courses in the health area of a certain institution of higher education in the municipality of Barra do Garças, Mato Grosso. From the results obtained, it is observed that, $90 \%$ of the students involved in the study are concerned with body image and are willing to change, although they are satisfied with their current image. 95\% of academics admitted to being influenced by the media in terms of beauty standards. However, despite the fact that academics are satisfied with their appearance, the desire to change the image due to media influence is evident.
\end{abstract}

Keywords: Body image, body, beauty pattern, satisfaction

\section{Introduction}

Body image is the illustration of our own body we produce in our mind, it is the way the body shows itself to us or as we know it. The body image is related to a representation that one has in mind, of size, image and shape of the body [1]. 
The care of the body is a major concern among the current generation, which seeks to be always adapting to reach what they consider acceptable. And this has led to aesthetics to gain a great position in society and in the lives of individuals who are always concerned to conform to beauty standards, causing many women to put themselves at risk with plastic surgeries, among other aesthetic procedures to achieve the body or beauty that the media shows and that society imposes as correct [2].

Beauty standards over the years are not static and over the years the beautiful body definition has gained several changes. As Moreno (2008) [3] quotes, it is with Barbie or Gisele Bundchen that girls and women want to look like today. After all, both are references to how society views them and values them.

One of the great influencers for people to pursue a pattern of beauty is the media, which has often shown pictures of models, artists, or very thin actresses with imaginatively perfect bodies, suggesting that this is the standard of beauty to which anyone should to adapt [4].

The media has a long and full story of change. It can be said that it has been progressing according to communication and technology, since one needs the other to reach the consumer [5].

Thus, the media, basically the internet and television, have influenced the disclosure and appreciation of the perfect body. They limit and portray at all times, places, spaces and definitions that influence individuals [6].

Mass media plays a critical role in the formation and thought of public opinion, reproducing the self-image of society. The excess of information related to beauty standards exposed everyday by digital media, televisions and magazines has led people to want the perfect body. This information is exposed primarily in social networks that are on the rise in the world today [7].

Damasceno et al. (2016) [8] state that dissatisfaction with body image increases as the media exposes beautiful bodies, a fact that in recent decades has provoked a compulsion to seek the ideal anatomy.

To reach the ideal body, many measures adopted by women favor the development of risky behaviors that can lead to a number of problems, such as eating disorders, excess physical activity, plastic surgery and others [9].

Thus, this study aimed to analyze the influence of the media on body self-perception in health academics, analyzing the importance of body image for them and daily habits related to body image.

\section{Materials and Methods}

The research was carried out through the application of a questionnaire with questions related to the subject, in a determined institution of higher education of the municipality of Barra do Garças, Mato Grosso. The questionnaire had eight closed questions and was applied in the month of May, only for the female public of the courses of the health area, such as nutrition, nursing, pharmacy and physiotherapy. The academics of the Aesthetics and Cosmetics course were not included in the research because they were directly related to the subjects that involve the corporal beauty.

After obtaining quantitative and qualitative data through the questions that were applied, the results were demonstrated in tables and figures forms. The study was done with a group of 60 women, aged between 17 and 45 years.

\section{Results and Discussion}

Table 1 shows the age range of the interviewed participants for the elaboration of the research. Where 51 participants presented age between 17 to 30 years and 9 of the participants presented age between 30 and 45 years, as shown in table 1.

Table 1. Age group of respondents

\begin{tabular}{lcc}
\hline Age & $n$ & $\%$ \\
17 to 30 years & 51 & $85 \%$ \\
30 to 45 years & 9 & $45 \%$ \\
\hline
\end{tabular}

The research was done only for the female audience, as women are more vulnerable to the pressures of these patterns. It occurs because women feel more pressured to follow a pattern of 
specific beauty or to be always in shape through a life accompanied by physical exercises and good nutrition.

Women are generally more concerned with body image. Many of them suffer from the influence of the media and the environment in which they live and, in turn, wish to decrease adiposity and conserve a leaner body with defined musculature and less flaccidity [10].

When asked about the concern with physical appearance the majority (90\%) of respondents said yes, while $10 \%$ claimed that they did not. When questioned about satisfaction with their body, $68 \%$ said they were satisfied, while $31 \%$ claimed they were not. Regarding media influence on the imposition of beauty standards, $95 \%$ of the interviewees believe that the media influence, while $5 \%$ do not believe in the influence of the media in relation to the imposition of beauty standards, as shown in table 2.

Table 2. Physical appearance, body satisfaction and media influence

\begin{tabular}{lcc}
\hline & $n$ & $\%$ \\
\hline $\begin{array}{l}\text { Concern about physical } \\
\text { appearance } \\
\text { Yes }\end{array}$ & 54 & $90 \%$ \\
No & 6 & $10 \%$ \\
$\begin{array}{l}\text { Satisfaction with the } \\
\text { body }\end{array}$ & & \\
$\begin{array}{l}\text { Yes } \\
\text { No }\end{array}$ & 41 & $68 \%$ \\
$\begin{array}{l}\text { Influence of the media } \\
\text { on the imposition of } \\
\text { beauty standards }\end{array}$ & 19 & $31 \%$ \\
Yes & & \\
No & 57 & $95 \%$ \\
\end{tabular}

According to the survey, most women interviewed are concerned about their current physical appearance. Given that this concern is increasing according to what is exposed every day in the media.

Currently, there is a desire to take the lean body as a model of influence, beauty and social stability. The ideal of body image is disseminated by the media, generating mainly in young women a dissatisfaction with the body. These, in turn, begin to look for attempts that may reach the current standard [11].

Aesthetic procedures have grown immensely in recent years. In Brazil alone, more than 2.5 million aesthetic procedures were performed, surgical or otherwise, leaving only the United States, which pointed out about three million procedures. The media influenced the pursuit of stereotyped beauty, emphasizing devotion to physical appearance [12].

A large number of respondents believe that the media influences the standards of beauty. For it has been used in various ways to indicate specific patterns of beauty. Make it of great interest for women to attain a popular trend. Every day we are bombarded with images of bodies called "perfect".

The media often have the power to create desires and accentuate images by standardizing bodies. Bodies that find themselves out of action feel burdened and dissatisfied. The media, by showing attractive bodies, causes a part of our society to launch in search of a desired physical appearance, without even considering the means [13].

When they were approached about body image, a large part of the students $(81 \%)$ said they had the desire to perform some changes in the body.

When questioned about the influence of beauty standards on self-esteem, 93\% of respondents said yes, while $7 \%$ stated that beauty standards do not influence. Of all the interviewees, $31 \%$ claimed to have already done some cosmetic procedure, and of these, $50 \%$ already had some influence from the media regarding aesthetic procedures, while another $50 \%$ claimed that they had not had any influence in this regard, as shown in table 3 .

Table 3. Body image and influences

\begin{tabular}{ll}
\hline$n$ & $\%$ \\
\hline
\end{tabular}

Desire for changes in the body

$\begin{array}{lll}\text { Yes } & 49 & 81 \% \\ \text { No } & 11 & 18 \%\end{array}$

Influence of patterns on selfesteem 


\begin{tabular}{lcc}
\hline Yes & 56 & $93 \%$ \\
No & 4 & $6 \%$ \\
$\begin{array}{l}\text { He was influenced to do some } \\
\text { procedure }\end{array}$ & \\
Yes & 30 & $50 \%$ \\
No & 30 & $50 \%$ \\
\hline
\end{tabular}

Both men and women are always willing to change some part in the body, because one of the relevant characteristics that affects the culture of appearance is the imposition by the slender body, which adds the idea of discipline and control.

Being overweight, on the other hand, is seen as incapacity, lack of control, laziness and lack of involvement with one's own body, causing people to feel dissatisfied with their appearance and thus causing these same people to change their physique [14].

Research has shown that the vast majority of scholars believe that the standards of beauty exposed by the media influence self-esteem. A negative body image can lead people to feel bad about their own mirror.

Due to the excessive appreciation of the woman's body, the publicity distributes the idea that happiness is acquired mainly through the exclusive consumption of products and treatments, being reinforced by the exaggeration of investments of the media in matters related to beauty and obtaining the perfect body, thus, the woman ends up achieving success, well-being and happiness, generating a high self-esteem [15].

In pursuit of an ideal body image, some people are subject to sacrifices, diets, ingestion of medications, making their self-esteem dependent on an idealized aesthetic pattern [16].

Cury (2005) [17] says that the various media and propaganda penetrated into the unconscious population introducing a broad untouchable aesthetic pattern, and that this dictatorship pressures and destroys the selfesteem of the human being, he further states that about 600 million of women feel that they are subject to this pattern and that $98 \%$ of women do not see themselves as beautiful and tend to look for aesthetic procedures.

A similar study with Brazilian university students in different regions showed that university students over 25 years of age are 23\% less likely to be influenced by the media than those under 19; that students with normal weight are 1.77 times more likely to be influenced by the media than those with low birth weight; and that overweight students are 1.74 times more likely to be influenced by the media than those with low weight [7].

Already in another study with the same line of investigation showed that the media had an enormous influence, however the interviewees did not perform the procedures to change their life or to transform into another person, only to perfect a certain part of the body that was considered as defective [18].

When questioned about how satisfied they are with their current physical appearance, $52 \%$ said they feel satisfied, $43 \%$ are not satisfied and $5 \%$ say they are dissatisfied, as shown in figure 1.

Figure 1. Degree of academic satisfaction with physical appearance

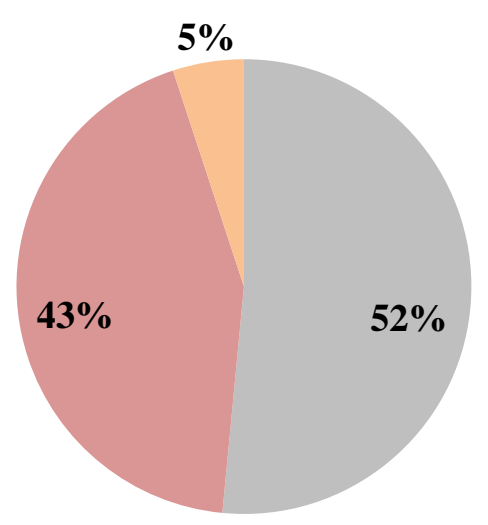

mmonplace among women who are always looking for a change.

Having a fuller or leaner body ends up being a derogatory thing in society, because body dissatisfaction is related to the exposure of beautiful bodies by the media and has determined, in the last decades, a compulsion to seek the ideal anatomy [19].

In a similar study, in terms of body satisfaction, 75 percent of respondents said they were satisfied with their physical appearance. Less than half $(25 \%)$ of the women interviewed 
stated they were dissatisfied or only partially satisfied with their bodies. Showing that the high level of satisfaction declared by women with their physical appearance contradicts the enormous consumption of Brazilian women by aesthetic services [20].

When they were approached about body care, $60 \%$ said they had a good diet and exercise, and $40 \%$ admitted not having these habits.

Figure 2. Physical activity and feeding care practice

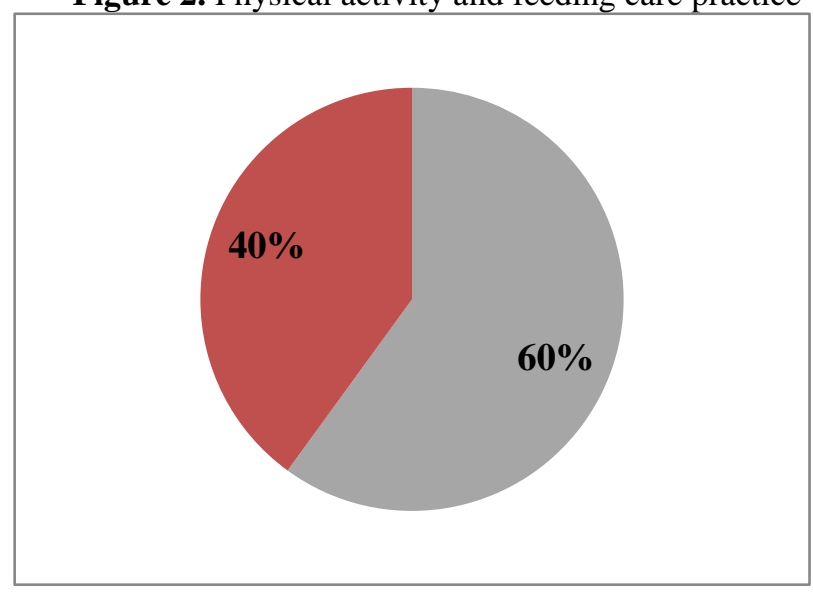

For most of the academics interviewed, to have a beautiful body and according to current standards of beauty is necessary to have a good diet and practice physical activity.

The female body is in continuous transformation, to follow the patterns of fashion, which has changed day by day. Through diets, medicine, clothing and cosmetics, women become more and more focused on the quest for ideal beauty [13].

Still Schneider (2009) [13] states that living longer, healthier and in good form, is now a concern that passes through much of a society. The figure of the beautiful and healthy body is in force in both the female and the male, in numerous age groups and social classes.

The media, regardless of their intonation, have certainly collaborated for this. Therefore, body care ends up being essential for those people who want to fit certain standards.

\section{Conclusions}

The vast majority of respondents claimed a desire to change some part in the body. However, what can be observed is that despite the fact that most academics claim to be satisfied with body image, the desire to change is evident, since society, especially the media, is a factor in spreading exaggerated concerns about body measurements. who feel pressured to seek a way to fit into a society full of exposed beauty standards.

It is perceived that the media has made people (especially women) increasingly seek to achieve a pattern of beauty created by various media. Such standards make women more and more vain.

However, it is important to remember that the aesthetic profession shows that besides beauty we should seek a positive satisfaction among all, and of course a full happiness.

\section{References}

1. BOSI, Maria Lúcia Magalhães et al.

Autopercepção da imagem corporal entre estudantes de nutrição: um estudo no município do Rio de Janeiro. J braspsiquiatr, v. 55, n. 2, p. 108-13, 2006.

2. BORBA, Tâmila. Uma reflexão sobre a influência da estética na autoestima, automotivação e bem-estar do ser humano. Universidade do vale do Itajaí, Univali Balneário Comburú, Santa Catarina, s.n. p.1-21, 2011.

\section{MORENO, Rachel. A beleza impossível:} mulher, mídia e consumo. $1^{\circ} \mathrm{Ed}$. Editora Ágora, 2008. 80 p.

4. MALDONADO, Gisela De Rosso. A educação física e o adolescente: a imagem corporal e a estética da transformação na mídia impressa. Revista Mackenzie de Educação

Física e Esporte, v. 5, n. 1, p. 3, 2009.

5. BATALINI, Beatriz Rodrigues et al. A influência da mídia nos padrões de beleza atuais. ETIC-ENCONTRO DE INICIAÇÃO CIENTÍFICA-ISSN 21-76-8498, v. 9, n. 9, p. 3, 2013.

6. FROIS, Erica; MOREIRA, Jacqueline; STENGEL, Márcia. Mídias e a imagem corporal na adolescência: o corpo em discussão. Psicologia em estudo, v. 16, n. 1, p.73, 2011. 
7. ALVARENGA, Marle dos Santos et al. Influência da mídia em universitárias brasileiras de diferentes regiões. Jornal Brasileiro de

Psiquiatria, v. 59, n. 2, p. 111-118, 2010.

8. DAMASCENO, Vinícius Oliveira et al. Imagem corporal e corpo ideal. Revista brasileira de ciência e movimento, v. 14, n. 2, p. 81-94, 2008.

9. OLIVEIRA, Leticia Langlois; HUTZ, Claúdio Simon. Transtornos alimentares: o papel dos aspectos culturais no mundo contemporâneo. Psicologia em estudo. Maringá. vol. 15, n. 3, p. 575-582., 2010.

10. BARBOSA, Ana Paula Dias Inocêncio. Imagem corporal em mulheres privadas de liberdade. 2017. Dissertação de Mestrado. Universidade Federal do Rio Grande do Norte, Centro de Ciências da Saúde, Natal, 2017.

11. BATISTA, Aline De Oliveira et al. Avaliação da autopercepção da imagem corporal em estudantesde estética e cosmética na Ulbra Torres. Conversas Interdisciplinares, v. 13, n. 3, p. 2, 2017.

12. FERREIRA, Juliana Barros; LEMOS, Larissa Morgan Andrade; DA SILVA, Thais Rocha. Qualidade de vida, imagem corporal e satisfação nos tratamentos estéticos. Revista Pesquisa em Fisioterapia, v. 6, n. 4, p.3, 2016.

13. SCHNEIDER, Aline Petter. Nutrição estética. $1^{a}$ ed. São Paulo: Atheneu, 2009. 327p.

14. JUSTINO, Maraísa Isabela Coelho et al. Autopercepção da imagem e satisfação corporal e estado nutricional de adolescentes. 2017.

15. BORIS, Georges Daniel JanjaBloc; DE HOLANDA CESÍDIO, Mirella. Mulher, corpo e subjetividade: uma análise desde o patriarcado à contemporaneidade. Revista Subjetividades, v. 7, n. 2, p. 451-478, 2007.

16. CARVALHO, Ana Margarida de Almeida. Satisfação corporal, auto-estima, autopercepção física e imagem dos instrutores de fitness. 2003. Trabalho de Conclusão de Curso.
17. CURY, Augusto Jorge. A ditadura da beleza e a revolução das mulheres. $1^{\circ} \mathrm{Ed}$. Rio de Janeiro. Editora Arqueiro, 2010. 208 p.

18. ROWE, Janaina Fatima; FERREIRA, Valéria; HOCH, Verena Augustin. Influência da mídia e satisfação com a imagem corporal em pessoas que realizaram cirurgia plástica. Unoesc \& Ciência-ACHS, v. 3, n. 1, p. 89-98, 2012.

19. SAUR, Adriana Martins; PASIAN, Sonia Regina. Satisfação com a imagem corporal em adultos de diferentes pesos corporais. Avaliação Psicológica, v. 7, n. 2, p. 199-209, 2008.

20. CHACHAM, Alessandra Sampaio; MAIA, Mônica Bara. Corpo e sexualidade da mulher brasileira. A mulher brasileira nos espaços público e privado, v. 1, p. 75-86, 2004. 